\title{
First Case Report of an Infant with Aplasia Cutis Congenita of Scalp and Myelomeningocele
}

\section{Primeiro relato de caso de aplasia cutis congenita e mielomeningocele}

\author{
Angelo Silva Neto ${ }^{1}$ Glena Marcelino $^{2}$ Cesar Garcia ${ }^{2}$ Isadora Dantas ${ }^{2}$ Isafran Silva ${ }^{2}$ Emerson Oliveira ${ }^{1}$ \\ 1 Pediatric Neurosurgery, Hospital Clóvis Sarinho, Natal, RN, Brazil \\ 2 Medical Student, Universidade Potiguar, Laureate International \\ Universities, Natal, RN, Brazil \\ Address for correspondence Angelo Silva Neto, MD, MSc, \\ Universidade Potiguar, Natal, Rio Grande do Norte, Brasil \\ (e-mail: angelo@neuronrn.com.br).
}

Arq Bras Neurocir 2016;35:152-156.

Abstract
Keywords
- ectodermal dysplasia
- hydrocephalus
- neuroendoscopy
- myelomeningocele

Resumo

Palavras-chave

- aplasia cútis congênita

- hidrocefalia

- espinha bífida
Aplasia cutis congenita of scalp (ACCS) is a rare developmental anomaly. It has presented in children who have many concomitant anomalies. Large, deep defects can complicate by repeat local and systemic sepsis and life-threatening hemorrhage. In this paper, we describe, to the best of our knowledge, the first case of a newborn boy with ACCS and myelomeningocele whose evolution with hydrocephalus has brought us a serious paradigm of using a shunt in the presence of tissue expanders. The treatment of hydrocephalus with third ventriculostomy associated with good aesthetic final result show an alternative to the use of shunt in this scenario, even in infants of young age. We review here therapeutic strategies and challenges with this disease.

A aplasia cútis congênita do couro cabeludo (ACC) é uma rara anomalia do desenvolvimento. Tem sido observada em pacientes com outras deformidades associadas. Formas extensas e profundas podem evoluir com septicemia e hemorragia grave. Neste trabalho descrevemos um caso inédito de neonato do sexo masculino com ACC e espinha bífida na qual a evolução com hidrocefalia nos trouxe um dilema em usar shunt na presença de expansores teciduais. O tratamento com terceiroventriculostomia endoscópica associado a um bom resultado estético revela uma alternativa ao uso de derivações neste cenário, mesmo em lactentes. Revisamos aqui as opções terapêuticas e desafios encontrados nesta patologia.

\section{Introduction}

Aplasia cutis congenita of the scalp (ACCS) is a rare congenital disease. ${ }^{1-3}$ The exact prevalence is still unknown. It was first described by Campbell in $1826 .{ }^{1}$ ACCS can be associated with other malformations characterizing genetic syndrome. ${ }^{3}$ The management involves conservative wound dressings in cases of small and superficial lesions. ${ }^{4}$ Conversely, cases with exposition of arachnoid, brain, and

received

January 12, 2016

accepted

March 26, 2016

published online

May 4, 2016
DOI http://dx.doi.org/

10.1055/s-0036-1583934 ISSN 0103-5355. sagittal sinus, at high risk of meningitis or hemorrhage require surgical repair. ${ }^{1,5} \mathrm{~A}$ significant number of these patients have concomitant congenital anomalies in the central nervous system (holoprosencephaly, hydrocephalus, myelomeningocele). ${ }^{5}$

Many patients with myelomeningocele develop hydrocephalus (from $52 \%$ to $92 \%$ ) and will undergo shunt placement. ${ }^{6}$ Cerebrospinal fluid (CSF) shunting has numerous
Copyright $\odot 2016$ by Thieme Publicações License terms Ltda, Rio de Janeiro, Brazil
(ब) $\Theta \circledast$ 
complications, notably infection. ${ }^{6,7}$ Endoscopic third ventriculostomy (ETV) has gained attention in recent years as an alternative to CSF shunting. Infants under 90 days of life and with myelomeningocele are at high risk of failure for ETV. ${ }^{6-9}$

We present a rare case of a newborn boy with a large ACCS and wide exposition of parietal cortex and superior sagittal sinus in association with lumbar myelomeningocele. Initially, we treated the ACCS with wound dressings. After two months, the emergence of hydrocephalus forced us to make a decision that could interfere with the use of tissue expanders. This decision was to put a CSF shunt and bring about a risk of infection and inadvertent manipulation of the shunt system. The choice of ETV enabled good control of hydrocephalus and enough time for closure of ACCS. We review the findings and therapeutic options for this unique presentation disease.

\section{Case Report}

\section{History and Presentation}

A newborn boy was referred for neurosurgical assessment due to suspected aplasia cutis congenita associated with spina bifida ( $\mathbf{- F i g . 1}$ ). He was born via cesarean section at 35 weeks from non-consanguineous parents. His birthweight was $2400 \mathrm{~g}$ and head circumference was $35.5 \mathrm{~cm}$.

Physical examination showed a full thickness dermal defect, affecting subcutaneous tissue, the galea aponeurotica, and including a large bone defect on the midline, between the parietal bones on the cranial vertex. There was a thin membrane covering the brain and the adjacent superior sagittal sinus, surrounded by skin with hyperemiated margins (-Fig. 2). There was a defect in the sacral region with upper limit at the border of L5-S1, demonstrating typical myelomeningocele. Genetic assessment confirmed Patau's syndrome.

\section{Treatment}

We initiated a conservative treatment of aplasia cutis with sulfadiazine cream. On the day of birth, we operated on the myelomeningocele and closed it using microsurgical techniques, with good approximation of the lateral margins on the midline.

Due to the progressive increase in head circumference, a cranial computerized tomography scan was performed at two months, revealing hydrocephaly associated with apparent obstruction of the fourth ventricular outlet ( - Fig. 3). Despite the significant possibility of therapeutic failure due to age, we

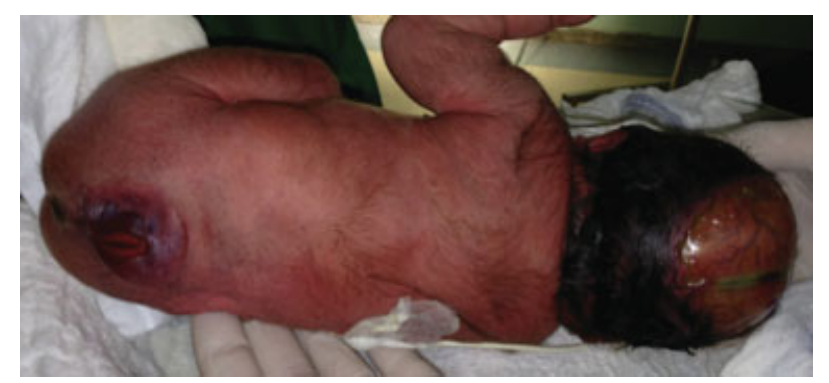

Fig. 1 Posterior view of large skull defect compatible with aplasia cutis in association with lumbar myelomeningocele.

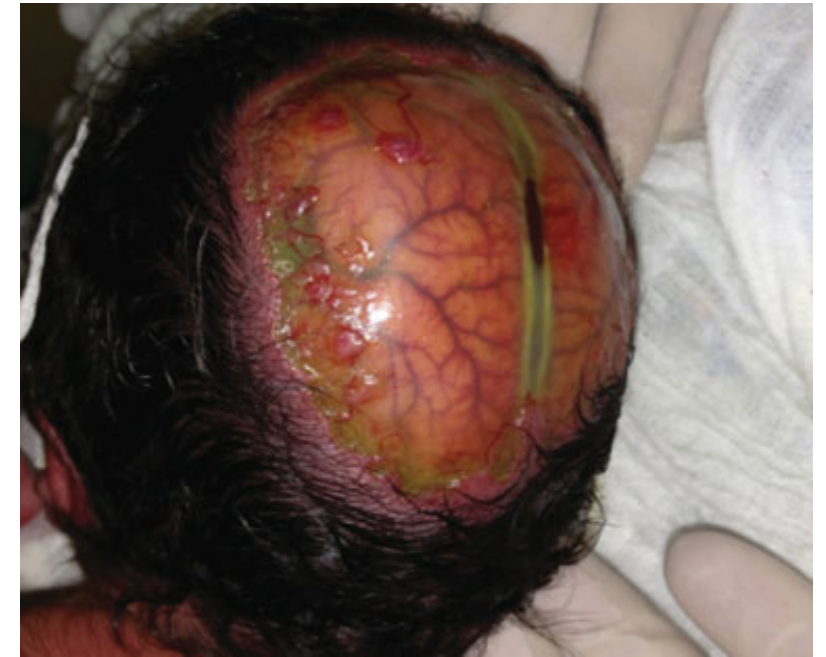

Fig. 2 Close-up view of parietal region showing the superior sagittal sinus surrounded by skin with hyperemiated margins.

treated the hydrocephaly with endoscopic third ventriculostomy (ETV). There was no suitable anatomic site to carry out trepanation on the parietal bone to place a shunt, and we sought to preserve the integrity of the skin for the use of subtissue expanders.

\section{Operation}

Endoscopic third ventriculostomy was performed under general anesthesia via left frontal trepanation without complications. The anatomy of the ventricular system was compatible with malformations seen in patients with type 2 Chiari. After three months of subcutaneous expander use, the aplasia cutis of the scalp was completely closed resulting in a good esthetic appearance (-Fig. 4). To date - 30-month follow-up - the use of shunts or other neurosurgical procedures has not been required.

\section{Discussion}

\section{Aplasia Cutis Congenita}

Aplasia cutis congenita (ACC) can occur at any site of the body, but primarily affects the cranium, more precisely the midline ${ }^{10}$ and parietal region. ${ }^{11}$ Most lesions are solitary and involve all layers, including the cranium and the dura mater, in $20 \%$ of patients. ${ }^{1}$ The exact prevalence and cause of this pathology is still unknown, and most cases are episodic. $^{3}$ Several authors have correlated the defect with a flaw in neural tube closure, pressure necrosis in cases of pelvic disproportion, or mechanical stress on the cranial vertex. $^{2}$

A large number of associated abnormalities have been described in patients with ACC, including defects in the central nervous, musculoskeletal, renal, and cardiac systems. ${ }^{3}$ Patau's syndrome (trisomy 13 ) is associated with serious defects in the central nervous system, including arhinencephaly and microphthalmia. ${ }^{12}$ We found no references in the literature of cases with ACC, Patau's syndrome, and myelomeningocele. Coexistence with defects in neural tube closure suggest a common embryological origin. 


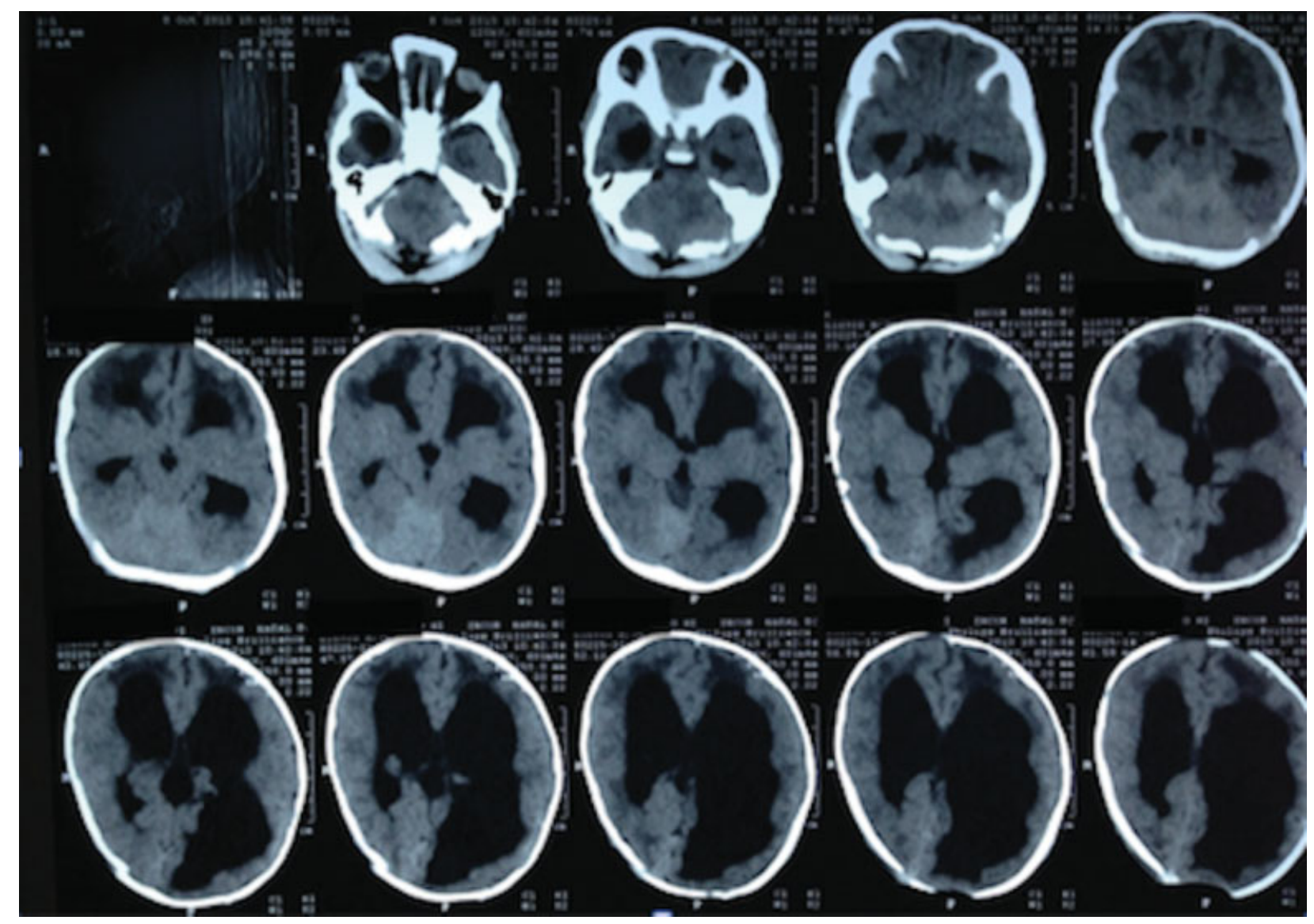

Fig. 3 CT scan showing hydrocephalus with small posterior fossa.

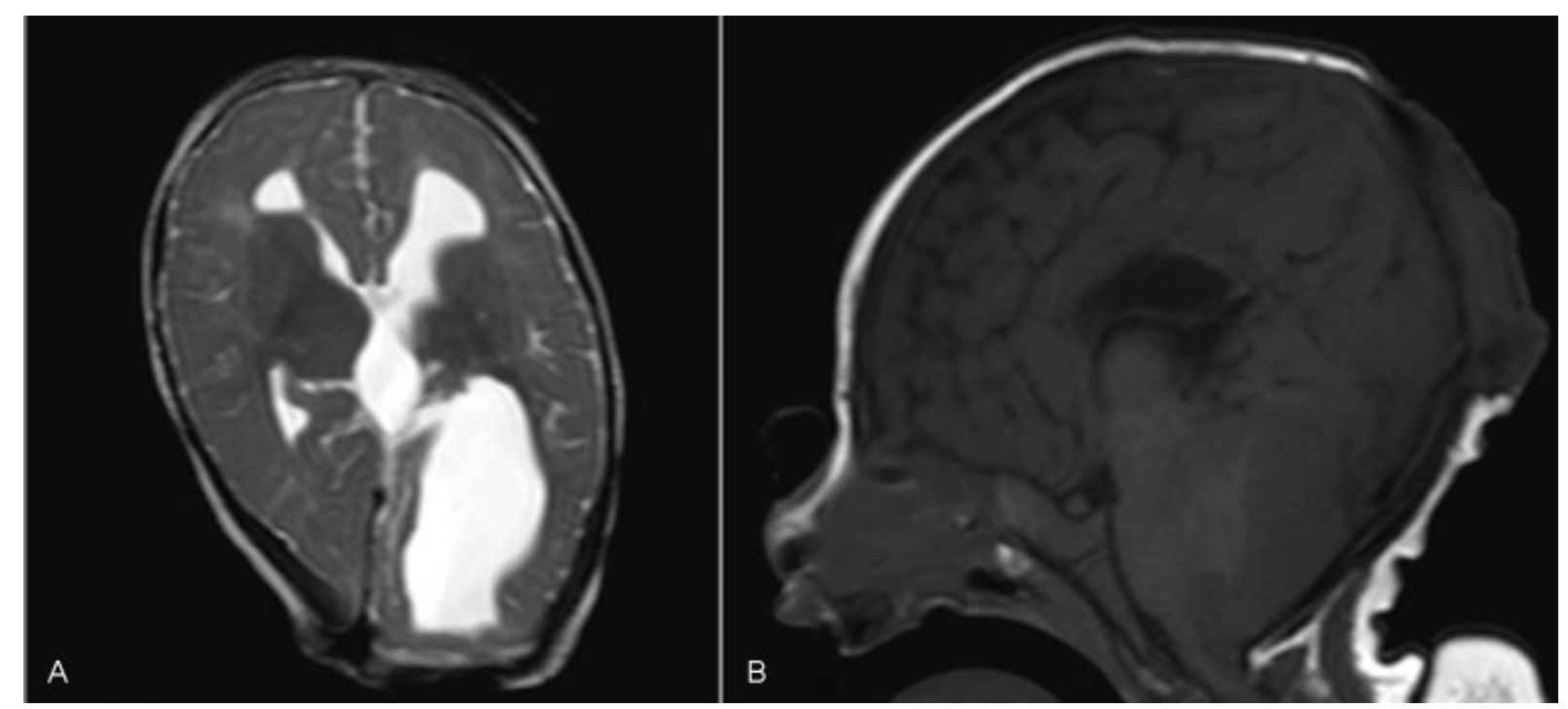

Fig. 4 (A) Axial T2-weighted MRI showing a good control of ventricle enlargement after 30 weeks of third ventriculostomy; (B) Sagittal T1-weighted MRI still showing a full posterior fossa compartment causing obstruction of III and IV ventricle. No pathological herniation of cerebellar tonsils.

Patients with ACC exhibit high mortality (25 to 55\%), associated with right cerebral lesion, venous hemorrhage (upper sagittal sinus), venous thrombosis, and infections. ${ }^{1}$ Thus, the treatment, whose primary objective is total closure of the defect, is indicated. It is recommended that this entire phase be conducted in a pediatric intensive care unit, where any clinical deterioration can be detected promptly. ${ }^{1}$

There are two treatment options for ACC. ${ }^{1-13}$ The conservative treatment, generally using daily dressings with sulfadiazine or bacitracin cream, is reserved for small defects. ${ }^{14}$ Large, deep defects, where there is prominent exposure of the upper sagittal 


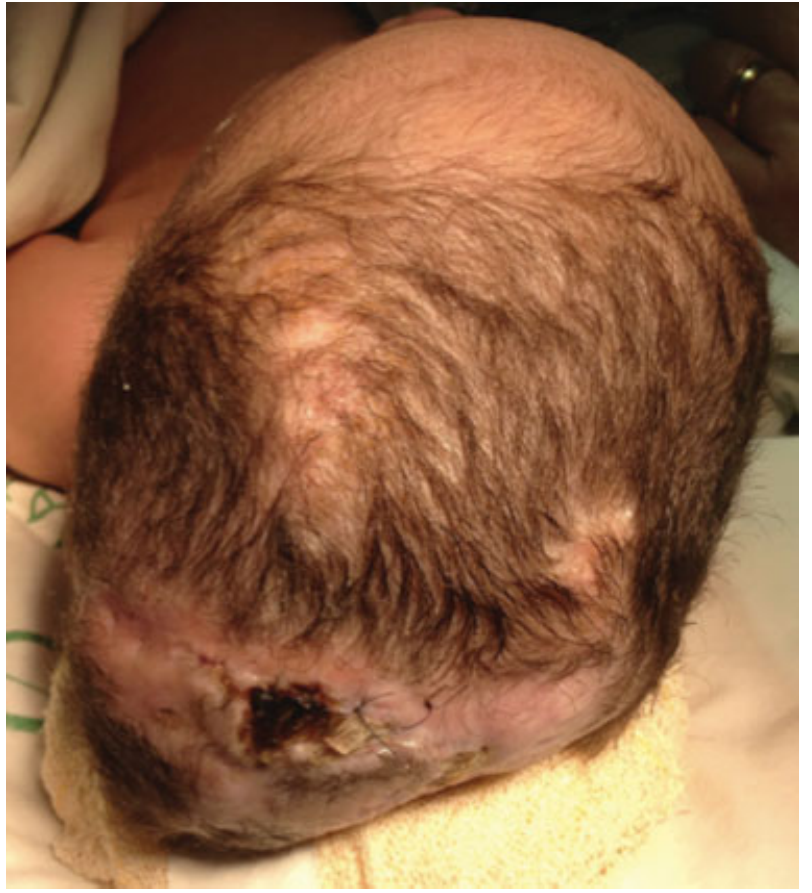

Fig. 5 Aesthetic result after closure of aplasia cutis.

sinus, should be treated surgically. ${ }^{4,5,15}$ The size to consider for surgical treatment remains controversial. According to Ross et al, defects larger than $5 \mathrm{~cm}$ in diameter should be treated surgically. ${ }^{16}$ Surgical techniques include rotation of adjacent skin flaps, pericranium flaps, and pedicle flaps (split rib grafts with a latissimus dorsi muscle flap). ${ }^{1,17}$ The use of tissue expanders are a good option in situations in which there is little skin around the ACC, as they allow adequate cutaneous rotation. ${ }^{18}$

\section{Hydrocephalus}

In infants with myelomeningocele (MMC), only $10 \%$ present as hydrocephalus at birth. Clinical signs of elevated intracranial pressure are indicators for treatment in association with increasing ventricular size. ETV is the only alternative to shunts for hydrocephalus in this group of patients. ${ }^{8}$ To decide on the best approach, we considered the imaging of small posterior fossa compartment as a point of obstruction of CSF flow. As an obstructive hydrocephalus, with no previous occurrence of venous thrombosis and infection we decided for ETV. Even though we knew that choroid plexus cauterization is worthwhile in this age group, ${ }^{8}$ for technical reasons we failed to achieve this target.

\section{Conclusions}

In our case, we used a combined technique, starting with daily dressings with silver sulfadiazine and, as the patient gained weight, we decided to place tissue expanders in the biparietal regions, resulting in a satisfactory final outcome after four months of hospitalization (-Fig. 5). The development of hydrocephaly during this process required that we choose a better therapeutic option that would not violate the ACCS area and would avoid increasing risk of infection to adjacent subcutaneous tissue, given that the patient used tissue expansion. Despite the known limitations and lower success rate of treatments with endoscopic third ventriculostomy in this age group, ${ }^{19}$ we achieved good control of hydrocephaly and correct skin closure after surgery.

In our research, we found no cases of ACCS associated with hydrocephaly treated with endoscopic third ventriculostomy. The author admits that he does not routinely perform ETV in patients with type 2 Chiari that are younger than six months. We presented here a rare, challenging case in which careful radiological assessment, sequential techniques, and the non-use of shunts resulted in a good clinical evolution.

\section{References}

1 Santos de Oliveira R, Barros Jucá CE, Lopes Lins-Neto A, Aparecida do Carmo Rego M, Farina J, Machado HR. Aplasia cutis congenita of the scalp: is there a better treatment strategy? Childs Nerv Syst 2006;22(9):1072-1079

2 Komuro Y, Yanai A, Seno H, et al. Surgical treatment of aplasia cutis congenita of the scalp associated with bilateral coronal synostosis. J Craniofac Surg 2002;13(4):513-519

3 Brzezinski P, Pinteala T, Chiriac AE, Foia L, Chiriac A. Aplasia cutis congenita of the scalp-what are the steps to be followed? Case report and review of the literature. An Bras Dermatol 2015;90(1): 100-103

4 Bernbeck B, Schwabe J, Groninger A, et al. Aplasia cutis congenita of the scalp: how much therapy is necessary in large defects? Acta Paediatr 2005;94(6):758-760

5 Harvey G, Solanki NS, Anderson PJ, Carney B, Snell BJ. Management of aplasia cutis congenita of the scalp. J Craniofac Surg 2012; 23(6):1662-1664

6 Phillips BC, Gelsomino M, Pownall AL, et al. Predictors of the need for cerebrospinal fluid diversion in patients with myelomeningocele. J Neurosurg Pediatr 2014;14(2):167-172

7 Jernigan SC, Berry JG, Graham DA, Goumnerova L. The comparative effectiveness of ventricular shunt placement versus endoscopic third ventriculostomy for initial treatment of hydrocephalus in infants. J Neurosurg Pediatr 2014;13(3): 295-300

8 Kulkarni AV, Riva-Cambrin J, Browd SR, et al; Hydrocephalus Clinical Research Network. Endoscopic third ventriculostomy and choroid plexus cauterization in infants with hydrocephalus: a retrospective Hydrocephalus Clinical Research Network study. J Neurosurg Pediatr 2014;14(3):224-229

9 Faggin R, Bernardo A, Stieg P, Perilongo G, d'Avella D. Hydrocephalus in infants less than six months of age: effectiveness of endoscopic third ventriculostomy. Eur J Pediatr Surg 2009;19(4):216-219

10 Nichols DD, Bottini AG. Aplasia cutis congenita. Case report. J Neurosurg 1996;85(1):170-173

11 Martínez-Lage JF, Almagro MJ, López Hernández F, Poza M. Aplasia cutis congenita of the scalp. Childs Nerv Syst 2002;18(11):634-637 , discussion 638

12 Torrelo A, Fernandez-Crehuet P, Del Prado E, et al. Extensive comedonal and cystic acne in Patau syndrome. Pediatr Dermatol 2010;27(2):199-200

13 Kruk-Jeromin J, Janik J, Rykała J. Aplasia cutis congenita of the scalp. Report of 16 cases. Dermatol Surg 1998;24(5):549-553

14 Dutra LB, Pereira MD, Kreniski TM, Zanon N, Cavalheiro S, Ferreira LM. Aplasia cutis congenita: management of a large skull defect with acrania. J Craniofac Surg 2009;20(4):1288-1292

15 Silva JC, Almeida JP, Serra S, et al. Aplasia cutis congenita of the scalp. Arq Neuropsiquiatr 2008;66(3B):752-754 
16 Ross DA, Laurie SW, Coombs CJ, Mutimer KL. Aplasia cutis congenita: failed conservative treatment. Plast Reconstr Surg 1995;95(1):124-129

17 Henriques JG, Pianetti Filho G, Giannetti AV, Henriques KS. [Large scalp and skull defect in patient with aplasia cutis congenita]. Arq Neuropsiquiatr 2004;62(4):1108-1111
18 Gibstein LA, Abramson DL, Bartlett RA, Orgill DP, Upton J, Mulliken JB. Tissue expansion in children: a retrospective study of complications. Ann Plast Surg 1997;38(4):358-364

19 Di Rocco C, Cinalli G, Massimi L, Spennato P, Cianciulli E, Tamburrini G. Endoscopic third ventriculostomy in the treatment of hydrocephalus in pediatric patients. Adv Tech Stand Neurosurg 2006;31:119-219 